\title{
Occurrence and identification of risk areas of Ixodes ricinus-borne pathogens: a cost- effectiveness analysis in north-eastern Italy
}

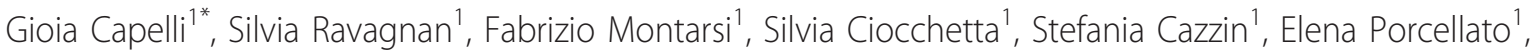
Amira Mustafa Babiker ${ }^{1}$, Rudi Cassini ${ }^{2}$, Annalisa Salviato ${ }^{1}$, Giovanni Cattoli ${ }^{1}$ and Domenico Otranto ${ }^{3}$

\begin{abstract}
Background: Ixodes ricinus, a competent vector of several pathogens, is the tick species most frequently reported to bite humans in Europe. The majority of human cases of Lyme borreliosis (LB) and tick-borne encephalitis (TBE) occur in the north-eastern region of Italy. The aims of this study were to detect the occurrence of endemic and emergent pathogens in north-eastern Italy using adult tick screening, and to identify areas at risk of pathogen transmission. Based on our results, different strategies for tick collection and pathogen screening and their relative costs were evaluated and discussed.
\end{abstract}

Methods: From 2006 to 2008 adult ticks were collected in 31 sites and molecularly screened for the detection of pathogens previously reported in the same area (i.e., LB agents, TBE virus, Anaplasma phagocytophilum, Rickettsia spp., Babesia spp., "Candidatus Neoehrlichia mikurensis"). Based on the results of this survey, three sampling strategies were evaluated a-posteriori, and the impact of each strategy on the final results and the overall cost reductions were analyzed. The strategies were as follows: tick collection throughout the year and testing of female ticks only (strategy A); collection from April to June and testing of all adult ticks (strategy B); collection from April to June and testing of female ticks only (strategy C).

Results: Eleven pathogens were detected in 77 out of 193 ticks collected in 14 sites. The most common microorganisms detected were Borrelia burgdorferi sensu lato (17.6\%), Rickettsia helvetica (13.1\%), and "Ca. N. mikurensis" (10.5\%). Within the B. burgdorferi complex, four genotypes (i.e., B. valaisiana, B. garinii, B. afzelii, and B. burgdorferi sensu stricto) were found. Less prevalent pathogens included R. monacensis (3.7\%), TBE virus (2.1\%), $A$. phagocytophilum (1.5\%), Bartonella spp. (1\%), and Babesia EU1 (0.5\%). Co-infections by more than one pathogen were diagnosed in $22 \%$ of infected ticks. The prevalences of infection assessed using the three alternative strategies were in accordance with the initial results, with 13,11 , and 10 out of 14 sites showing occurrence of at least one pathogen, respectively. The strategies $A, B$, and $C$ proposed herein would allow to reduce the original costs of sampling and laboratory analyses by one third, half, and two thirds, respectively. Strategy B was demonstrated to represent the most cost-effective choice, offering a substantial reduction of costs, as well as reliable results.

\footnotetext{
* Correspondence: gcapelli@izsvenezie.it

'Istituto Zooprofilattico Sperimentale delle Venezie, Viale dell'Università, 10,

35020, Legnaro (Pd), Italy

Full list of author information is available at the end of the article
} 
Conclusions: Monitoring of tick-borne diseases is expensive, particularly in areas where several zoonotic pathogens co-occur. Cost-effectiveness studies can support the choice of the best monitoring strategy, which should take into account the ecology of the area under investigation, as well as the available budget.

Keywords: Ixodes ricinus, tick-borne diseases, surveillance, economic evaluation, Italy.

\section{Background}

Ticks are second only to mosquitoes as vectors of zoonotic pathogens and are recognized as the primary vectors of vector-borne diseases in temperate climates [1].

Ixodes ricinus (Acari: Ixodidae), also known as "wood", "sheep" or "castor-bean" tick, is the ixodid species most frequently reported to bite humans in Europe [2], and acts as a major vector of viral, bacterial, and protozoan agents, which infect many domesticated and wild animals, as well as humans [3]. For instance, this species can transmit the tick-borne encephalitis virus (TBEv), Borrelia burgdorferi sensu lato (s.l.), the aetiological agent of Lyme borreliosis (LB), as well as other pathogens, e.g. Rickettsia, Anaplasma and Babesia spp. [4]. The distribution of tick-transmitted pathogens (TTPs) is primarily dependent on tick density and the availability of animal reservoirs. I. ricinus acts as vector of several pathogens mostly because of its large host spectrum, being able to feed on more than 300 animal species [2].

In Italy, I. ricinus occurs throughout the peninsula and its populations reach the highest density in hilly and pre-alpine northern areas, characterized by a temperate climate, with cold winters, and cool and humid summers [5]. These areas represent the optimal I. ricinus biotope, consisting of microhabitats characterized by humidity above $85 \%$ and a well conserved biocenosis of wild animals (including small and large mammals, birds, and reptiles). The north-eastern region of Italy accounts for the majority of human cases of LB and TBE [6]; the first cases of Human Granulocytic Anaplasmosis (HGA) by Anaplasma phagocytophilum have also been reported in the same area $[7,8]$.

According to Heiman et al. [1], tick-borne diseases (TBDs) are also likely to become among the infectious threats, one of the main concerns for public health in Europe within the coming years; therefore, well planned, efficient, and cost-effective surveillance systems need to be implemented. The first step towards planning TBDs surveillance should consist in assessing the panel of pathogens occurring in a given area and their relative epidemiological importance, in relation to their prevalence in vectors and hosts and the severity of the diseases that they cause. Alongside burden of pathogens, information on vector density and dynamics also needs to be aquired. In order to assess the spatial and temporal distribution of I. ricinus and the environmental factors associated with its occurrence in north-eastern Italy, the Ministry of
Health launched a three year-project (code RC-IZSVe $11 / 04$ ), whose results have been published elsewhere $[9,10]$. In the present study, adult ticks collected through the previous years were screened for all the pathogens known or suspected to occur in north-eastern Italy, including TBEv, LB agents, A. phagocytophilum, Rickettsia spp., Babesia spp. and the recently described bacterium "Candidatus Neoehrlichia mikurensis".

The aims of this study were to assess the suitability of adult tick screening for (i) detecting the occurrence of endemic and emergent pathogens in north-eastern Italy, and (ii) identifying areas at risk for pathogen transmission to animals and humans. Based on the results of this survey, different strategies for collection of ticks and pathogen screening, as well as their relative costs, were evaluated and discussed.

Over the past few years, central and local Governments have drastically reduced funds to the majority of institutions involved in monitoring vector-borne diseases. This will inevitably impact on ways of approaching research and surveillance actions in terms of sampling design, and data collection and analyses.

\section{Methods}

\section{Study area}

From 2006 to 2008, I. ricinus ticks were collected in an area of north-eastern Italy $\left(45^{\circ} 30^{\prime} 52^{\prime \prime} \mathrm{N}\right.$ to $46^{\circ} 32^{\prime} 44^{\prime \prime} \mathrm{N}$ and $11^{\circ}$ 9'52"E to $\left.13^{\circ} 1^{\prime} 14 " \mathrm{E}\right)$ within the regions of Veneto and Friuli Venezia Giulia (FVG), including five provinces (i.e., Vicenza, Verona, Treviso, Pordenone, and Udine) (Figure 1).

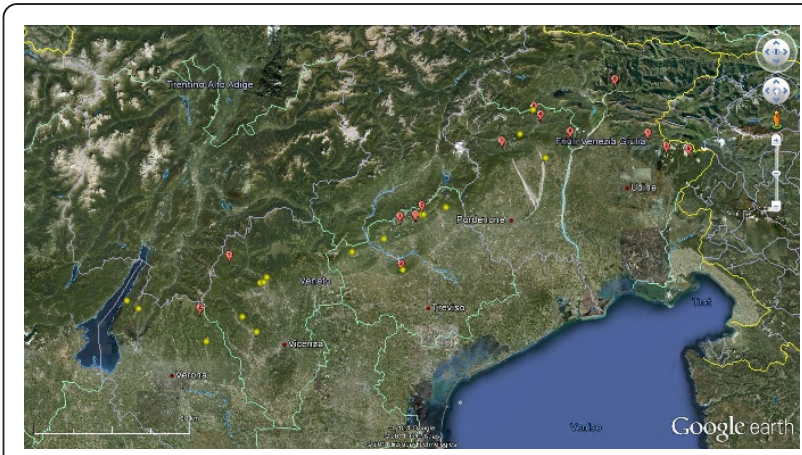

Figure 1 Map of north-eastern Italy showing the 31 sites in which adult ticks were found (yellow: sites negative for pathogens; red: sites positive for one or more pathogens; number of pathogens/ site is also reported within each red symbol). 
Sampling was carried out in the south-eastern slope of hilly and pre-alpine areas in habitats suitable for growth and survival of $I$. ricinus, characterized by heterogeneous deciduous woodland and mixed forest, and occurrence of domestic and/or wild animals. The altitudes of the sites investigated ranged between 120 and $1308 \mathrm{~m}$ above sea level (a.s.l.). All sites were close to human dwellings or easily accessible through footpaths.

\section{Tick sampling and identification}

From 2006 to 2008 a permanent site for each province was monitored monthly, whereas another 50 sites were monitored on one occasion each month (herein after defined as temporary sites). Ticks were collected by dragging using a $1 \mathrm{~m}^{2}$ white flannel cloth, through $50 \mathrm{~m}$ transects, stopping every $2.5 \mathrm{~m}$ to prevent their detachment. Once collected, ticks were kept refrigerated at + $4^{\circ} \mathrm{C}$, counted, grouped according to their developmental stage, and identified based on morphological features [11]. All adults collected throughout the three years at 31 sites ( 5 permanents and 26 temporary) were molecularly processed.

\section{Biomolecular analyses for the identification of pathogens and sequencing}

Nucleic acids were extracted from single adult ticks using All Prep DNA/RNA mini Kit (Qiagen, Inc., Valencia, CA), according to the manufacturer's instructions and then kept frozen at $-80^{\circ} \mathrm{C}$. Target genes, primers, and probes used for testing and the size of the PCR amplification products are listed in Table 1 and 2.

To ensure the effectiveness of the nucleic acid extraction, a real time PCR targeting the $16 \mathrm{~S}$ rRNA was applied [12].

Table 1 Biomolecular method used for pathogen identification, target genes, primers, probes and references.

\begin{tabular}{|c|c|c|c|c|c|c|}
\hline Species & method & gene & primers & Nucleotide sequence $\left(5^{\prime}-3^{\prime}\right)$ & $\begin{array}{l}\text { Amplicon } \\
\text { size (bp) }\end{array}$ & Ref. \\
\hline |xodes & PCR & $16 S$ ribosomal RNA & F-16slxodes & AAAAAAATACTCTAGGGATAACAGCGTAA & 97 & {$[12]$} \\
\hline \multirow{2}{*}{$\begin{array}{l}\text { (extraction } \\
\text { control) }\end{array}$} & & & R-16slxodes & ACCAAAAAAGAATCCTAATCCAACA & & \\
\hline & & & $\begin{array}{l}\text { 16s-Ixodes- } \\
\text { Probe }\end{array}$ & $\begin{array}{l}\text { TITGGATAGTTCATATAGATAAAATAGTTTGC } \\
\text { GACCTCG }\end{array}$ & & \\
\hline \multirow[t]{3}{*}{ B. burgdorferi s.l. } & $\begin{array}{l}\text { real time PCR } \\
\text { (duplex) }\end{array}$ & 23S-rRNA & $\mathrm{Bb} 23 \mathrm{Sf}$ & CGAGTCTTAAAAGGGCGATTTAGT & 75 & [14] \\
\hline & & & $\mathrm{Bb} 23 \mathrm{Sr}$ & GCTTCAGCCTGGCCATAAATAG & & \\
\hline & & & Bb23Sp-FAM & AGATGTGGTAGACCCGAAGCCGAGTG & & \\
\hline \multirow[t]{3}{*}{$\begin{array}{l}\text { A. } \\
\text { phagocytophilum }\end{array}$} & $\begin{array}{l}\text { real time PCR } \\
\text { (duplex) }\end{array}$ & msp2 & ApMSP2f & ATGGAAGGTAGTGTTGGTTATGGTATT & 77 & [14] \\
\hline & & & ApMSP2r & TTGGTCTTGAAGCGCTCGTA & & \\
\hline & & & ApMSP2p-HEX & TGGTGCCAGGGTTGAGCTTGAGATTG & & \\
\hline \multirow[t]{2}{*}{ B. burgdorferi s.l. } & PCR & flagellin & FLA1 & AGAGCAACTTACAGACGAAATTAAT & 482 & [16] \\
\hline & & & FLA2 & CAAGTCTATITGGAAAGCACCTAA & & \\
\hline \multirow{2}{*}{$\begin{array}{l}\text { A. } \\
\text { phagocytophilum }\end{array}$} & PCR & msp2 & msp2-3f & CCAGCGTTTAGCAAGATAAGAG & 334 & {$[15]$} \\
\hline & & & msp2-3r & GMCCAGTAACAACATCATAAGC & & \\
\hline \multirow[t]{3}{*}{ TBEv } & rRT-PCR & $3^{\prime}$ non-coding region & F-TBE 1 & GGGCGGTTCTTGTTCTCC & 67 & {$[12]$} \\
\hline & & & R-TBE 1 & ACACATCACCTCCTTGTCAGACT & & \\
\hline & & & TBE-Probe-WT & TGAGCCACCATCACCCAGACACA & & \\
\hline \multirow[t]{4}{*}{ TBEV } & nested PCR & $\begin{array}{l}\text { non-structural protein } \\
\text { NS5 }\end{array}$ & FSM-1 & GAGGCTGAACAACTGCACGA & 357 & [13] \\
\hline & & & FSM-2 & GAACACGTCCATTCCTGATCT & & \\
\hline & & $\begin{array}{l}\text { non-structural protein } \\
\text { NS5 }\end{array}$ & FSM-1i & ACGGAACGTGACAAGGCTAG & 251 & \\
\hline & & & FSM-2i & GCTTGTTACCATCTITGGAG & & \\
\hline \multirow[t]{2}{*}{ Rickettsia spp. } & $P C R$ & citrate synthase & RpCS.877p & GGGGGCCTGCTCACGGCGG & 381 & {$[17]$} \\
\hline & & & RpCS1258n & ATTGCAAAAAGTACAGTGAACA & & \\
\hline \multirow{2}{*}{$\begin{array}{l}\text { Cand. N. } \\
\text { mikurensis }\end{array}$} & PCR & groEL & NM-128s & AACAGGTGAAACACTAGATAAGTCCAT & 1024 & {$[19]$} \\
\hline & & & NM-1152as & TTCTACTITGAACATTTGAAGAATTACTAT & & \\
\hline \multirow[t]{2}{*}{ Babesia/Theileria } & PCR & $18 \mathrm{~S}$ rRNA & RLB-F2 & GACACAGGGAGGTAGTGACAA & 400 & [18] \\
\hline & & & RLB-R2 & CTAAGAATTTCACCTCTGACAGT & & \\
\hline
\end{tabular}


Table 2 Primers and UPL used for genospecies identification of Borrelia burgdorferi s.I. in co-infected ticks using real time PCR assays

\begin{tabular}{|c|c|c|c|c|}
\hline Genospecies & Target gene & $5^{\prime} \rightarrow$ 3'primer sequence & UPL number & $\begin{array}{l}\text { Amplicon } \\
\text { size (bp) }\end{array}$ \\
\hline B. burgdorferi s.s. & $\mathrm{OspA}^{\mathrm{a}}$ & $\begin{array}{l}\text { TCTTGAAGGAACTTTAACTGCTGA } \\
\text { TGAAACTTCCCCAGATTTGA }\end{array}$ & $\# 119$ & 97 \\
\hline B. afzelii & OspA & $\begin{array}{l}\text { GACTCCGCAGGTACCAATTT } \\
\text { AAAGCGTIITAAGTTCATCAAGTG }\end{array}$ & \#98 & 71 \\
\hline B. garinii & $\mathrm{Fla}^{\mathrm{b}}$ & TCTGCTATGATTATGCCACCA CCTITGCCTAAGAATTGATTACCA & $\# 2$ & 74 \\
\hline B. valaisiana & Fla & $\begin{array}{l}\text { CCAAATGCACATGTTGTCAAA } \\
\text { TTTGCAGGTTGCATTCCA }\end{array}$ & $\# 132$ & 78 \\
\hline
\end{tabular}

${ }^{\mathrm{a}}$ OspA: Outer surface protein A gene; ${ }^{\mathrm{b}} \mathrm{Fla:}$ flagellin gene; ${ }^{\mathrm{c} b p}$ : base pairs

A real time PCR was used for TBEV detection [12]. Positive results in real-time PCR were confirmed by a nested real time (RT)-PCR [13]. A multiplex RT-PCR was used for the simultaneous detection of $A$. phagocytophilum and B. burgdorferi s.l. [14].

All samples positive for $A$. phagocytophilum were confirmed by a specific PCR [15] and sequenced. To determine the genospecies of B. burgdorferi s.l., a conserved region of the flagellin gene was amplified by PCR for all the $B$. burgdorferi s.l. positive samples according to a protocol previously published [16], followed by genetic sequencing of the PCR products. Sequence electropherograms of B. burgdorferi s.l. were checked for quality and to reveal the presence of double nucleotide peaks. When double peaks were detected in both (i.e., for primers forward and reverse) high-quality sequence electropherograms and their location corresponded to the variable sites specific for a certain genospecies, a multiple infection was suspected. To confirm the presence of co-infections of B. burgdorferi genospecies, four RT-PCR assays were performed by using Universal Probe Library (UPL) (Roche, Mannheim, Germany), presynthesized, fluorescence-labelled locked nucleic acid (LNA) hydrolysis probes, to detect specifically B. burgdorferi s.s., $B$. afzelii, B. garinii and B. valaisiana. Primers and probes number (Table 2) were chosen by free online software (UPL Assay Design Center web service; https://www. roche-applied-science.com) and the UPL probe from the Roche Universal Probe Library collection. Real time PCR was performed with a reaction mixture consisting of $2 \mu \mathrm{l}$ of DNA, $5 \mu \mathrm{l}$ of $2 \times$ Light Cycler 480 Probes Master (Roche, Mannheim, Germany), $300 \mathrm{nM}$ of each Borrelia species primer set and $200 \mathrm{nM}$ of each corresponding UPL probe with a thermal cycling profile consisting of an initial activation at $95^{\circ} \mathrm{C}$ for $10 \mathrm{~min}$, followed by 45 cycles of denaturation at $95^{\circ} \mathrm{C}$ for $10 \mathrm{~s}$ and annealing/extension at $60^{\circ} \mathrm{C}$ for $30 \mathrm{~s}$ and a final cooling step at $40^{\circ} \mathrm{C}$ for $30 \mathrm{~s}$. Fluorescence data were collected in the annealing/extension phase at $60^{\circ} \mathrm{C}$.

Rickettsia spp., Babesia spp., and "Ca. N. mikurensis" were amplified with protocols described in the literature
[17-19] and the species identity determined by genetic sequencing.

RT-PCRs were carried out on a Rotor Gene 6000 realTime PCR system (Corbett, Australia) and traditional PCRs on a GeneAmp ${ }^{\circledR}$ PCR System 9700 thermal cycler (Applied Biosystems, Foster City, CA).

All PCR products were sequenced using the Big Dye Terminator v 3.1 cycle sequencing kit (Applied Biosystem, Foster City, CA, USA). The products of the sequencing reactions were purified using PERFORMA DTR Ultra 96-Well kit (Edge BioSystems, Gaithersburg, MD, USA) and sequenced in a 16-capillary ABI PRISM $3130 \times 1$ Genetic Analyzer (Applied Biosystem, Foster City, CA, USA). Sequence data were assembled and edited with SeqScape software v 2.5 (Applied Biosystem, Foster City, CA, USA), aligned and compared with representative sequences available in GenBank.

\section{Statistical analysis}

Differences in the prevalence of pathogens in relation to tick gender, province/region of origin, and month/year of collection were tested by using $\chi^{2}$ or Fisher's exact test, when appropriate. The correlation between number of adults examined and number of pathogens recovered was tested by linear regression. The software used was SPSS (SPSS Inc., Chicago, IL) for windows, version 13.0.

\section{Cost estimation}

Costs of molecular procedures were calculated as described by Cattoli et al. [20], adjusted for DNA/RNA extraction used in this study. Travel costs (distance range from the sites, i.e., $62-218 \mathrm{~km}$ ), included fuel, tolls and meals for staff involved in tick collections. Costs for staff were calculated based on the number of working days and on staff salary scales of Istituto Zooprofilattico Sperimentale delle Venezie, Italy (2011).

\section{Results}

Occurrence of pathogens and co-infections

During the 146 dragging collections performed throughout the three years, 193 adult ticks (i.e., 95 females and 
Table 3 Pathogens and their prevalence (P) detected in 193 adult Ixodes ricinus from 2006 to 2008 in north-eastern Italy, permanent and temporary sites positives and year of detection.

\begin{tabular}{|c|c|c|c|c|c|c|c|}
\hline \multirow[t]{2}{*}{ Pathogens [accession numbers] } & \multirow{2}{*}{$\begin{array}{l}\text { pos. } \\
\text { ticks }\end{array}$} & \multirow[t]{2}{*}{$\mathbf{P}$} & \multirow{2}{*}{$\begin{array}{l}\text { perm. } \\
\text { sites } \\
n=5\end{array}$} & \multirow{2}{*}{$\begin{array}{l}\text { temp. } \\
\text { sites } \\
n=26\end{array}$} & \multicolumn{3}{|c|}{ year of detection } \\
\hline & & & & & $\begin{array}{l}2006 \\
n=43\end{array}$ & $\begin{array}{l}2007 \\
n=83\end{array}$ & $\begin{array}{l}2008 \\
n=67\end{array}$ \\
\hline Borrelia burgdorferi s.l. & 34 & $17.6 \%$ & & & & & \\
\hline B. valaisiana [GU581273] & 12 & $6.2 \%$ & 2 & 3 & $x$ & $x$ & $x$ \\
\hline B. afzelii [GU581269, GU581270] & 10 & $5.2 \%$ & 2 & 2 & $x$ & $x$ & $x$ \\
\hline B. garinii [GU581274-GU581277] & 8 & $4.1 \%$ & 1 & 3 & $x$ & $x$ & - \\
\hline B. burgdorferi s.s. [GU581271, GU581272] & 6 & $3.1 \%$ & 2 & 3 & $x$ & $x$ & $x$ \\
\hline Rickettsia helvetica* [JQ669952, JQ669953] & 25 & $13.1 \%$ & 4 & 5 & $x$ & $x$ & $x$ \\
\hline Ca. Neoehrlichia mikurensis* [JQ669946] & 20 & $10.5 \%$ & 3 & 3 & $x$ & $x$ & $x$ \\
\hline R. monacensis* [JQ669950, JQ669951] & 7 & $3.7 \%$ & - & 3 & $x$ & - & - \\
\hline TBE flavivirus [JQ669945] & 4 & $2.1 \%$ & 1 & - & - & $x$ & - \\
\hline $\begin{array}{l}\text { Anaplasma phagocytophilum [JQ669947, } \\
\text { JQ669948, JQ669949] }\end{array}$ & 3 & $1.5 \%$ & 2 & 1 & - & $x$ & - \\
\hline Bartonella spp. & 2 & $1.0 \%$ & 2 & - & - & $x$ & - \\
\hline Babesia EU1 (B. venatorum)* [JQ669954] & 1 & $0.5 \%$ & 1 & - & - & - & $x$ \\
\hline Total & 77 & $39.9 \%$ & 5 & 9 & & & \\
\hline
\end{tabular}

GenBank accession numbers are also reported.

* adult tested 191

97 males) were collected in 31 sites (range 1-47 ticks per site). At least one pathogen was detected in 77 (39.9\%) ticks from 14 sites (45\%). Overall, 11 pathogens were identified with variable prevalence (Table 3 ), with B. burgdorferi s.l. the most common (17.6\%), followed by $R$. helvetica (13.1\%) and "Ca. N. mikurensis" (10.5\%). Four genotypes within the B. burgdorferi complex (i.e., $B$. valaisiana, B. garinii, B. afzelii, and B. burgdorferi sensu stricto) were identified. TBE virus, $A$. phagocytophilum, R. monacensis, and Babesia EU1 (proposed name $B$. venatorum) were detected more rarely (Table 3). GenBank accession numbers of the most representative sequences are reported in Table 3.

The overall pathogen infection rate was significantly higher in females than in male ticks (46.2\% vs. $29.9 \%$; p $<0.01$ ); considering single species, this difference was significant $(\mathrm{p}<0.05)$ only for B. burgdorferi s.l., B. garinii and $R$. helvetica. All pathogens were detected in the permanent sites examined, with the exception of $R$. monacensis which was only detected in temporary sites (Table 3 ). Whilst highly prevalent pathogens (i.e., LB agents, $R$. helvetica and "Ca. N. mikurensis") were detected in both permanent and temporary sites, those with low prevalence rates (e.g., TBEv, Bartonella spp., and Babesia EU1) were only detected in permanent sites (Table 3), most likely due to the high intensity of sampling. Out of 77 positive ticks, 60 (78\%) harboured a single infection, $13(17 \%)$ were co-infected by two pathogens, and $4(5 \%)$ by three pathogens. Pathogen associations are reported in Table 4 which describes the co-infections detected in 13 female and in 4 male ticks $(\mathrm{p}<0.05)$.

\section{Pathogen spatial and temporal distribution}

Pathogen prevalence and species diversity in spatial distribution were different in the five provinces monitored (Table 5), with the Northern provinces (i.e., Udine, Pordenone, and Treviso) displaying the highest adult tick density and composition of pathogen species (Figure 1). In particular, out of 11 TTPs, 8 and 10 were detected only in Treviso and Udine, respectively. The higher

\section{Table 4 Pathogen association in co-infected ticks}

\begin{tabular}{ll}
$\begin{array}{l}\text { Co-infected ticks } \\
\text { double co-infection }\end{array}$ & Pathogen associations \\
\hline 3 & R. helvetica-B. garinii \\
3 & R. helvetica-Ca. N. mikurensis \\
1 & R. monacensis-B. afzelii \\
1 & R. monacensis-Ca. N. mikurensis \\
1 & R. monacensis-B. valaisiana \\
1 & B. afzelii-Ca. N. mikurensis \\
1 & B. garinii/B. valaisiana \\
1 & B. garinii-Ca. N. mikurensis \\
1 & TBE-B. burgdorferi s.S. \\
triple co-infection & TBE-B. burgdorferi s.S.-B. afzelii \\
\hline 1 & R. monacensis-B. afzelii-Ca. N. mikurensis \\
1 & R. monacensis-B. burgdorferi S.S.-Ca. N. mikurensis \\
1 & B. valaisiana-Babesia EU1-Ca. N. mikurensis \\
\hline 1 &
\end{tabular}


Table 5 Pathogens prevalence according to province of origin (permanent and temporary sites all over the three years) and significant differences*

\begin{tabular}{|c|c|c|c|c|c|c|c|c|c|c|}
\hline \multirow{3}{*}{$\begin{array}{l}\text { provinces } \\
\text { pathogens }\end{array}$} & \multicolumn{4}{|c|}{ Friuli Venezia Giulia region } & \multicolumn{6}{|c|}{ Veneto region } \\
\hline & \multicolumn{2}{|c|}{$\begin{array}{l}\text { Pordenone } \\
n=47\end{array}$} & \multicolumn{2}{|l|}{$\begin{array}{l}\text { Udine } \\
n=60\end{array}$} & \multicolumn{2}{|l|}{$\begin{array}{l}\text { Treviso } \\
\mathrm{n}=64\end{array}$} & \multicolumn{2}{|l|}{$\begin{array}{l}\text { Vicenza } \\
\mathrm{n}=10\end{array}$} & \multicolumn{2}{|l|}{$\begin{array}{l}\text { Verona } \\
n=12\end{array}$} \\
\hline & pos ticks & $\%$ & pos ticks & $\%$ & pos ticks & $\%$ & pos ticks & $\%$ & pos ticks & $\%$ \\
\hline Lyme agents: & 14 & $29.8^{\mathrm{a}}$ & 8 & $13.3^{\mathrm{a}}$ & 10 & 15.6 & - & - & 2 & 16.7 \\
\hline B. valaisiana & 3 & 6.4 & 2 & 3.3 & 5 & 7.8 & - & - & 2 & 16.7 \\
\hline B. afzelii & 8 & $17.0^{\mathrm{b}}$ & 2 & $3.3^{b}$ & - & - & - & - & - & - \\
\hline B. garinii & 2 & 4.3 & 3 & 5.0 & 3 & 4.7 & - & - & - & - \\
\hline B. burgdorferi s.s. & 2 & 4.3 & 2 & 3.3 & 2 & 3.1 & - & - & - & - \\
\hline R. helvetica & 6 & 13.0 & 6 & 10.0 & 10 & 15.6 & 1 & 10.0 & 2 & 16.7 \\
\hline Ca. N. mikurensis & 9 & 19.6 & 5 & 8.3 & 6 & 9.4 & - & - & - & - \\
\hline R. monacensis & 6 & $13.0^{c}$ & 1 & $1.7^{c}$ & - & - & - & - & - & - \\
\hline TBEv & - & - & 4 & 6.7 & - & - & - & - & - & - \\
\hline A. phagocytophilum & - & - & 2 & 3.3 & 1 & 1.6 & - & - & - & - \\
\hline Bartonella spp & - & - & 1 & 1.7 & 1 & 1.6 & - & - & - & - \\
\hline Babesia EU1 & - & - & - & - & 1 & 1.6 & - & - & - & - \\
\hline Total & 36 & $76.6^{\mathrm{ABCd}}$ & 28 & $46.7^{\mathrm{Ae}}$ & 29 & $45.3^{B}$ & 1 & $10.0^{\mathrm{Ce}}$ & 4 & $33.3^{\mathrm{d}}$ \\
\hline
\end{tabular}

* Equal letter corresponds to significant difference (lower case $=p<0.05$; upper case $=p<0.01$ )

overall prevalence of TTPs in Pordenone was linked specifically to infections by $B$. afzelii, $R$. monacensis and "Ca. N. mikurensis". Despite the small number of adult ticks (Table 5) collected in the southern provinces (i.e., Verona and Vicenza), high prevalent pathogens ( $R$. helvetica and $B$. valaisiana) were detected in the same areas. All pathogens except Babesia EU1 were detected in FVG region, whereas $R$. monacensis, B. afzelii, and $\mathrm{TBEv}$ were not detected in adult ticks in Veneto region.

The number of pathogens identified ranged from one to seven per single site (Figure 1) and, in general, the number of ticks/site was positively correlated $\left(R^{2}=\right.$ 0.83 ) with the number of pathogens detected. Interestingly, up to six pathogens were detected in 13 adults ticks collected in a single temporary site of the Treviso province. Although ticks and pathogens could be found from February to December throughout the three years of sampling, the density of adult ticks peaked in May and June, with all the 11 TTPs detected from April to June.

\section{Possible scenarios for tick sampling and pathogen screening}

Based on the results of this study, three different tick collection scenarios were pictured, and the results obtained compared with those above. The strategies hypothesized were as follows: tick collection throughout the year and testing of female ticks only (strategy A); collection from April to June and testing of adult male and female ticks (strategy B); collection from April to June and testing of female ticks only (strategy C).
The results of the three alternative strategies are summarized in Table 6. The prevalence of TTPs assessed using these three protocols did not differ significantly from the results of the initial screening. The prevalence calculated at province level resulted in a pathogen scenario similar to that of the initial screening for strategy $A$ and $B$, whereas the small number $(n=67)$ of ticks collected in strategy $\mathrm{C}$ led to very high prevalence confidence intervals (data not shown).

The occurrence of all the 11 pathogens was confirmed by strategy $B$, while strategies $A$ and $C$ did not allow detection of sporadic pathogens (i.e., Bartonella spp., Babesia EU1), which were exclusively harboured by male ticks in this study. Out of 14 sites where pathogens were detected in the initial screening, 13, 11, and 10 were positive for pathogens using strategy A, B and C, respectively. The decrease in the number of ticks screened resulted in a loss of pathogen species detected in each single site. In particular, strategies $\mathrm{A}, \mathrm{B}$, and $\mathrm{C}$ did not allow the detection of 1-2 pathogens in 7, 3 and 7 sites, respectively.

Estimated costs (i.e., laboratory, travel and staff expenses) for the three strategies proposed are illustrated in Table 7. Compared with the initial screening, the costs of alternative strategies $\mathrm{A}, \mathrm{B}$ and $\mathrm{C}$ were reduced by approximately one third, half and two thirds, respectively. Pros and cons of each strategy are illustrated in Table 8.

\section{Discussion}

The collection of adult ticks over a three-year period combining the use of permanent and temporary 
Table 6 Pathogen prevalence according to the initial screening (all adults) and different sampling strategies (A, B, C) and prevalence difference among each strategy compared to the initial screening $(\Delta)$

\begin{tabular}{|c|c|c|c|c|c|c|c|c|c|c|c|}
\hline \multirow{3}{*}{ Pathogens } & \multirow{2}{*}{\multicolumn{2}{|c|}{$\begin{array}{l}\text { all adults } \\
\mathrm{n}=193\end{array}$}} & \multicolumn{3}{|c|}{ Strategy $A$} & \multicolumn{3}{|c|}{ Strategy $B$} & \multicolumn{3}{|c|}{ Strategy $C$} \\
\hline & & & \multicolumn{2}{|c|}{$\begin{array}{l}\text { female ticks } \\
\text { all year } \\
n=95\end{array}$} & \multirow{2}{*}{$\begin{array}{l}\Delta \\
\%\end{array}$} & \multicolumn{2}{|c|}{$\begin{array}{l}\text { all ticks } \\
\text { April-June } \\
\mathrm{n}=127\end{array}$} & \multirow{2}{*}{$\begin{array}{l}\Delta \\
\%\end{array}$} & \multicolumn{2}{|c|}{$\begin{array}{l}\text { female ticks } \\
\text { April-June } \\
n=67\end{array}$} & \multirow{2}{*}{$\begin{array}{l}\Delta \\
\%\end{array}$} \\
\hline & pos & $\%$ & pos & $\%$ & & pos & $\%$ & & pos & $\%$ & \\
\hline B. burgdorferi s.l. & 34 & 17.6 & 23 & 24.2 & 6.6 & 19 & 15.0 & 2.6 & 14 & 20.9 & 3.3 \\
\hline B. valaisiana & 12 & 6.2 & 6 & 6.3 & 0.1 & 6 & 4.7 & -1.5 & 4 & 6.0 & -0.2 \\
\hline B. afzelii & 10 & 5.2 & 7 & 7.4 & 2.2 & 4 & 3.1 & -2.0 & 2 & 3.0 & -2.2 \\
\hline B. garinii & 8 & 4.1 & 7 & 7.4 & 3.2 & 7 & 5.5 & 1.4 & 6 & 9.0 & 4.1 \\
\hline B. burgdorferi s.s. & 6 & 3.1 & 5 & 5.3 & 2.2 & 4 & 3.1 & 0.0 & 4 & 6.0 & 2.9 \\
\hline R. helvetica & 25 & 13.1 & 18 & 19.1 & 6.1 & 20 & 15.7 & 2.7 & 14 & 21.2 & 8.1 \\
\hline Ca. N. mikurensis & 20 & 10.5 & 8 & 8.5 & -2.0 & 11 & 8.7 & -1.8 & 5 & 7.6 & -2.0 \\
\hline R. monacensis & 7 & 3.7 & 3 & 3.2 & -0.5 & 2 & 1.6 & -2.1 & 1 & 1.5 & -2.2 \\
\hline TBEv & 4 & 2.1 & 4 & 4.2 & 2.1 & 4 & 3.1 & 1.1 & 4 & 6.0 & 3.9 \\
\hline A. phagocytophilum & 3 & 1.6 & 3 & 3.2 & 1.6 & 3 & 2.4 & 0.8 & 3 & 4.5 & 2.9 \\
\hline Bartonella spp. & 2 & 1.0 & 0 & 0.0 & -1.0 & 2 & 1.6 & 0.5 & 0 & 0.0 & -1.0 \\
\hline Babesia EU1 & 1 & 0.5 & 0 & 0.0 & -0.5 & 1 & 0.8 & 0.3 & 0 & 0.0 & -0.5 \\
\hline Total & 77 & 39.9 & 44 & 46.3 & 6.4 & 50 & 39.4 & -0.5 & 31 & 46.3 & 6.4 \\
\hline
\end{tabular}

sampling sites provided relevant information on the occurrence of pathogens in the area under investigation. Up to 11 pathogens were detected in about $40 \%$ of $I$. ricinus individuals sampled from north-eastern Italy, with one or more pathogens occurring in 14 collection sites. The pathogens detected in the present study had already been identified from 1989 to date in I. ricinus collected in the same area [3,21-32], with the exception of $B$. lusitaniae, which was detected once in nymphs [33], and $B$. divergens which was isolated from cattle only [34]. However, this study reports a comprehensive survey of TTPs occurring at one time in this area.

LB agents and Rickettsia species were the most prevalent pathogens in ticks and are therefore regarded as the most likely transmissible agents to animals and humans in this area. The study monitored and confirmed the occurrence of other emergent pathogens, such as $A$. phagocytophilum, and Babesia EU1. Interestingly, it also ascertained the presence and the distribution of " $\mathrm{Ca}$. $\mathrm{N}$. mikurensis" for the first time in Italy. The relevant prevalence of ticks positive to "Ca. N. mikurensis" (more than 10\%) is of particular interest considering the role of this pathogen as the aetiological agent of human infections in Germany, Switzerland, and Sweden [35-37] and in a dog in Germany [19]. Indeed, following the primary isolation from rats (Rattus norvegicus) and Ixodes ovatus ticks [38] in Japan, this bacterium has been included in the list of emerging pathogens in Europe [39]. TBEv and A. phagocytophilum were detected in a few sites of those monitored (Table 3). The low prevalence and the scattered distribution patterns recorded for these agents, which often occur in local foci of transmission [40,41], complicates monitoring of tick vectors, calling for the use of other tools, such as serological

Table 7 Estimated costs $(€)$ of different tick sampling strategies and pathogen screening for a three year study

\begin{tabular}{|c|c|c|c|c|c|c|c|c|}
\hline & \multicolumn{2}{|c|}{ All ticks } & \multicolumn{2}{|c|}{ Strategy A } & \multicolumn{2}{|c|}{ Strategy B } & \multicolumn{2}{|c|}{ Strategy C } \\
\hline & $n$ & $€$ & $\mathrm{n}$ & $€$ & $\mathrm{n}$ & $€$ & $\mathrm{n}$ & $€$ \\
\hline DNA/RNA extraction (x2) & 388 & 3706 & 190 & 2438 & 254 & 1824 & 134 & 1286 \\
\hline biomolecular analyses & 1018 & 7010 & 510 & 3516 & 669 & 4608 & 359 & 1634 \\
\hline sequencing & 101 & 1818 & 59 & 1062 & 81 & 1458 & 55 & 990 \\
\hline draggings (travel costs) & 146 & 24000 & 146 & 24000 & 71 & 9000 & 71 & 9000 \\
\hline \multicolumn{9}{|l|}{ Staff } \\
\hline 1 grant (sampling) & 96 & 7234 & 96 & 7234 & 36 & 2713 & 36 & 2713 \\
\hline 1 entomologist & 32 & 4874 & 16 & 2399 & 21 & 3207 & 11 & 1692 \\
\hline 1 technician & 64 & 7932 & 32 & 3905 & 42 & 5220 & 22 & 2754 \\
\hline 1 biotechnologist & 112 & 26507 & 56 & 13277 & 75 & 17758 & 41 & 9697 \\
\hline $\begin{array}{l}\text { Total } \\
\text { (reduction of costs) }\end{array}$ & & 83081 & & $\begin{array}{l}57832 \\
(30 \%)\end{array}$ & & $\begin{array}{l}45788 \\
(45 \%)\end{array}$ & & $\begin{array}{l}29765 \\
(64 \%)\end{array}$ \\
\hline
\end{tabular}


Table 8 Pros and cons of strategies A, B, and C in terms of results and costs

\begin{tabular}{|c|c|c|}
\hline Strategies description & PROS & CONS \\
\hline $\begin{array}{l}\text { Strategy A } \\
\text { (pathogen detection in female ticks } \\
\text { collected all over the year) }\end{array}$ & $\begin{array}{l}\text { Good general pathogen detection } \\
\text { in the area } \\
\text { Good identification of risk sites } \\
\text { Good pathogen prevalence } \\
\text { assessment }\end{array}$ & $\begin{array}{l}\text { No detection of sporadic } \\
\text { pathogens } \\
\text { High loss of single pathogen } \\
\text { detections per site } \\
\text { Low reduction of general costs } \\
(30 \%) \\
\text { No reduction of travel costs }\end{array}$ \\
\hline \multirow[t]{2}{*}{$\begin{array}{l}\text { Strategy B } \\
\text { (pathogen detection in all ticks } \\
\text { collected in the period April-June) }\end{array}$} & $\begin{array}{l}\text { Excellent pathogen detection in } \\
\text { the area } \\
\text { Excellent pathogen prevalence } \\
\text { assessment } \\
\text { Low loss of single pathogen } \\
\text { determination per site } \\
\text { High reduction of travel costs (62\%) }\end{array}$ & $\begin{array}{l}\text { Medium efficiency in identifying } \\
\text { risk sites } \\
\text { Low reduction of laboratory } \\
\text { costs (33\%) }\end{array}$ \\
\hline & Detection of sporadic pathogens & \\
\hline $\begin{array}{l}\text { Strategy C } \\
\text { (pathogen detection in female ticks } \\
\text { collected in the period April-June) }\end{array}$ & $\begin{array}{l}\text { Good general pathogen detection } \\
\text { in the area } \\
\text { High reduction of general and } \\
\text { specific costs (64\%) }\end{array}$ & $\begin{array}{l}\text { Low efficiency of pathogen } \\
\text { prevalence assessment at local level } \\
\text { Non detection of sporadic pathogens } \\
\text { High loss of pathogen detection } \\
\text { per site }\end{array}$ \\
\hline
\end{tabular}

methods and clinical case reports, for supporting surveillance strategies. Bartonella spp. was also detected in I. ricinus and, in spite of the increasing number of infections reported in ticks $[42,43]$, the role played by $I$. ricinus in the transmission of this pathogen to animals and humans is disputable. However, recent laboratory evidence showed that the transmission of Bartonella birtlesii by $I$. ricinus ticks may occurr in naive mice [44].

Twenty-seven percent of positive ticks displayed coinfections by two or even three pathogens. Co-infections have been frequently reported in Europe not only in questing ticks $[45-47,43,48]$, but also in ticks removed from humans [49], as well as domestic and wild animals [50,51].

Co-infections in questing $I$. ricinus confirm the wide host range of this tick species and the role played by mammals, such as small rodents, or birds, as reservoirs of several pathogens simultaneously. The frequent finding of co-infections in adult ticks should stimulate an increased awareness of physicians and veterinarians of potential multiple infections in vertebrate hosts, leading to different or atypical clinical presentations [52].

The present study indicates that screening of adult ticks is a successful strategy to maximize the probability of pathogen detection. The rationale for monitoring adult ticks is that the pathogen rate of infection in adult questing ticks is usually higher than in nymphs, as a consequence of the transtadial transmission of agents accumulated during the blood meal on different hosts [52].

However, despite the fact that the original screening strategy was focussed on a relatively small number of adult ticks, this strategy had considerable costs (table 7). Hence, other sampling strategies were hypothesized $a$ - posteriori, in order to evaluate their effeciency in terms of data collected and reduction of costs. Reducing the sampling time to three months (strategies B and C) instead of the whole year, decreased costs consistently (i.e., travel and staff costs), by reducing the draggings from the initial 146 to 71 . Nonetheless, strategy C resulted in a loss of data, especially at local level (provinces and sites).

Specific screening of female ticks (strategies A and C) was justified by the higher pathogen rate of infection found in I. ricinus females compared to males. Nevertheless, the screening of females only resulted in the fact that sporadic pathogens were not detected.

Strategy B (processing of all adult ticks from April to June) was the most cost-effective choice, and represented the best compromise for both cost reduction and reliability of results (Table 8 ). Therefore, this strategy is recommended as basis for circulation studies of TTPs in this specific context. However, other areas characterized by different climate, tick dynamics, and pathogen prevalence may need modifications in terms of sample size and time of tick collection.

\section{Conclusions}

The actions that should be planned in a surveillance programme vary according to objectives (e.g., detection of major zoonotic pathogens only or emergent ones as well), ecological characteristics of pathogens to examine, estimation of costs, and budget availability. When dealing with a TBD, systematic tick collections should be undertaken in order to assess the size of the vector population and the pathogen infection rates. According to the European Center for Diseases Control [53] local, national and international health authorities should 
control the occurrence of a given vector-borne disease, e.g. endemic or non-endemic diseases.

This study indicates that, in the ecological landscape of north-eastern Italy, a complete picture of TTPs occurrence and of areas at risk of transmission can be drawn by systematic screening of adult ticks throughout a three-year time frame. These data can support decision makers to plan further surveillance activities. Nevertheless, tick collection and pathogen detection are expensive, especially in areas where several zoonotic TTPs coexist. Strategy B here proposed proved to fulfil the original aims of the study, being also costeffective.

In addition, a thoughtful optimization of the diagnostic procedures could contribute to reduce costs, enabling a comprehensive, cost-effective, broad spectrum detection platform. Under the above circumstances, advanced biomolecular technologies, such as suspension array, reverse line blot hybridization, and novel sequencing technologies (e.g., pyrosequencing or next generation sequencing), have opened new perspectives towards maximizing results and reducing costs at the same time. The use of more sensitive approaches is likely to increase the number of pathogen species detected, as well as of co-infections diagnosed in a given area.

\footnotetext{
Acknowledgements and Funding

This study was supported by the Italian Ministry of Health (project codes RCIZSVe 11/04 and RC-IZSVe 07/07) and by the Veneto region.

Publication of the CVBD7 thematic series has been sponsored by Bayer Animal Health $\mathrm{GmbH}$.

Authors wish to thank Vincenzo Lorusso and Cinzia Cantacessi for their helpful comments on the text.

Authors wish to thank too the colleagues who provided the positive controls for PCRs: Alessandra Torina (Rickettsia conorii) of the National Reference Centre for Anaplasma, Babesia, Rickettsia and Theileria (CRABaRT), Sicily, Italy; Bernard Carcy (Babesia divergens, strain Rouen 1987) of the Laboratoire de Biologie cellulare et moleculaire, Montpellier, France; Martin Pfeffer ("Candidatus Neoehrlichia mikurensis", field strain from I. ricinus) of the Institut für Tierhygiene und Öffentliches Veterinärwesen, University of Leipzig, Germany; Maria Grazia Ciufolini (TBE virus, strain HYPR) of the Istituto Superiore di Sanità, Rome, Italy; Marco Martini (Anaplasma phagocytophilum, field strain from I. ricinus) of the Faculty of Veterinary Medicine, University of Padua, Italy; Alda Natale (European strain B. burgdorferi N34) of the Immunology Laboratory, Istituto Zooprofilattico Sperimentale delle Venezie. Authors would like to also thank all the colleagues of Local Veterinary Units of Veneto and Friuli Venezia Giulia regions, who helped with the choice of sites and collection of ticks throughout the years.
}

\section{Author details}

'Istituto Zooprofilattico Sperimentale delle Venezie, Viale dell'Università, 10, 35020, Legnaro (Pd), Italy. ${ }^{2}$ Dipartimento di Scienze Sperimentali Veterinarie, Università degli Studi di Padova, 35020 Legnaro, Padova, Italy. ${ }^{3}$ Dipartimento di Sanità Pubblica e Zootecnia, Università degli Studi di Bari, 70010 Valenzano, Bari, Italy.

\section{Authors' contributions}

GC and FM conceived the study. FM, RC, and SC conducted the field study and the identification of ticks. SR, EP, AMB, SC, AS, GC, RC performed the biomolecular analyses and sequencing. GC, SR, and DO wrote the paper. All the authors read and approved the final manuscript.

\section{Competing interests}

G. Capelli and DO are members of the Bayer CVBD World Forum. The authors declare that there is no conflict of interest regarding the present work and that the sponsor had no role in study design, data collection and analysis, decision to publish, or preparation of the manuscript.

Received: 3 January 2012 Accepted: 27 March 2012

Published: 27 March 2012

\section{References}

1. Heyman P, Cochez C, Hofhuis A, van der Giessen J, Sprong H, Porter SR, Losson B, Saegerman C, Donoso-Mantke O, Niedrig M, Papa A: A clear and present danger: tick-borne diseases in Europe. Expert Rev Anti Infect Ther 2010, 8(1):33-50.

2. Gern L: The biology of the Ixodes ricinus tick. Ther Umsch 2005, 62(11):707-12.

3. Carpi G, Cagnacci F, Wittekindt NE, Zhao F, Qi J, Tomsho LP, Drautz DI, Rizzoli A, Schuster SC: Metagenomic profile of the bacterial communities associated with Ixodes ricinus ticks. PLoS One 2011, 6(10):e25604.

4. Gern L, Lienhard R, Péter O: Diseases and pathogenic agents transmitted by ticks in Switzerland. Rev Med Suisse 2010, 6(266):1906-9.

5. Rizzoli A, Rosà R, Mantelli B, Pecchioli E, Hauffe H, Tagliapietra V, Beninati T, Neteler M, Genchi C: Ixodes ricinus, transmitted diseases and reservoirs. Parassitologia 2004, 46(1-2):119-22.

6. Ciceroni L, Ciarrocchi S, Ciervo A, Mondarini V, Guzzo F, Caruso G, Murgia R, Cinco M: Isolation and characterization of Borrelia burgdorferi sensu lato strains in an area of Italy where Lyme borreliosis is endemic. J Clin Microbiol 2001, 39(6):2254-60.

7. Ruscio M, Cinco M: Human granulocytic ehrlichiosis in Italy: first report on two confirmed cases. Ann N Y Acad Sci 2003, 990:350-2.

8. Beltrame A, Ruscio M, Arzese A, Rorato G, Negri C, Londero A, Crapis M, Scudeller L, Viale P: Human granulocytic anaplasmosis in northeastern Italy. Ann N Y Acad Sci 2006, 1078:106-9.

9. Corrain R, Montarsi F, Maioli G, Danesi P, Cassini R, Capelli G: Ecological factors affecting the abundance of Ixodes ricinus in areas of Veneto and Friuli Venezia Giulia region, north-eastern Italy. Parassitologia 2008, 50(suppl 1-2):106.

10. Tagliapietra V, Rosà R, Arnoldi D, Cagnacci F, Capelli G, Montarsi F, Hauffe HC, Rizzoli A: Saturation deficit and deer density affect questing activity and local abundance of Ixodes ricinus (Acari, Ixodidae) in Italy. Vet Parasitol 2011, 183(1-2):114-24.

11. Manilla G: Fauna d'Italia. Acari Ixodida Bologna, Italy, Calderini Press; 1998.

12. Schwaiger M, Cassinotti P: Development of a quantitative real-time RTPCR assay with internal control for the laboratory detection of tick borne encephalitis virus (TBEV) RNA. J Clin Virol 2003, 27(2):136-45.

13. Puchhammer-Stöckl E, Kunz C, Mandl CW, Heinz FX: Identification of tickborne encephalitis virus ribonucleic acid in tick suspensions and in clinical specimens by a reverse transcription-nested polymerase chain reaction assay. Clin Diagn Virol 1995, 4(4):321.

14. Courtney JW, Kostelnik LM, Zeidner NS, Massung RF: Multiplex real-time PCR for detection of Anaplasma phagocytophilum and Borrelia burgdorferi. J Clinical Microbiol 2004, 42(7):3164-3168.

15. Massung RF, Slater KG: Comparison of PCR assays for detection of the agent of human granulocytic ehrlichiosis, Anaplasma phagocytophilum. J Clin Microbiol 2003, 41(2):717-22.

16. Skotarczak B, Wodecka B, Cichocka A: Coexistence DNA of Borrelia burgdorferi sensu lato and Babesia microti in Ixodes ricinus ticks from north-western Poland. Ann Agric Environ Med 2002, 9(1):25-8.

17. Marquez FJ, Muniain MA, Soriguer RC, Izquierdo G, Rodriguez-Bano J, Borobio MV: Genotypic identification of an undescribed spotted fever group Rickettsia in Ixodes ricinus from southwestern Spain. Am J Trop Med Hyg 1998, 58(5):570-7.

18. Centeno-Lima S, do Rosário V, Parreira R, Maia AJ, Freudenthal AM, Nijhof AM, Jongejan F: A fatal case of human babesiosis in Portugal: molecular and phylogenetic analysis. Trop Med Int Health 2003, 8(8):760-4.

19. Diniz PP, Schulz BS, Hartmann K, Breitschwerdt EB: "Candidatus Neoehrlichia mikurensis" infection in a Dog from Germany. J Clin Microbiol 2011, 49(5):2059.

20. Cattoli G, Drago A, Maniero S, Toffan A, Bertoli E, Fassina S, Terregino C, Robbi C, Vicenzoni G, Capua I: Comparison of three rapid detection 
systems for type A influenza virus on tracheal swabs of experimentally and naturally infected birds. Avian Pathol 2004, 33(4):432-7.

21. Cinco M, Banfi E, Trevisan G, Stanek G: Characterization of the first tick isolate of Borrelia burgdorferi from Italy. APMIS 1989, 97(4):381-2.

22. Cinco M, Padovan D, Murgia R, Maroli M, Frusteri L, Heldtander M, Engvall EO: Coexistence of Ehrlichia phagocytophila and Borrelia burgdorferi sensu lato in Ixodes ricinus ticks from Italy as determined by 16S rRNA gene sequencing. J Clin Microbiol 1997, 35(12):3365-6.

23. Favia G, Cancrini G, Carfi A, Grazioli D, Lillini E, lori A: Molecular identification of Borrelia valaisiana and HGE-like Ehrlichia in Ixodes ricinus ticks sampled in north-eastern Italy: first report in Veneto region. Parassitologia 2001, 43(3):143-6.

24. Hudson PJ, Rizzoli A, Rosà R, Chemini C, Jones LD, Gould EA: Tick-borne encephalitis virus in northern Italy: molecular analysis, relationships with density and seasonal dynamics of Ixodes ricinus. Med Vet Entomol 2001, 15(3):304-13.

25. Beninati T, Lo N, Noda H, Esposito F, Rizzoli A, Favia G, Genchi C: First detection of spotted fever group rickettsiae in Ixodes ricinus from Italy. Emerg Infect Dis 2002, 8(9):983-6.

26. Sanogo YO, Parola P, Shpynov S, Camicas JL, Brouqui P, Caruso G, Raoult D: Genetic diversity of bacterial agents detected in ticks removed from asymptomatic patients in Northeastern Italy. Ann NY Acad Sci 2003, 990:182-190.

27. Koutaro M, Santos AS, Dumler JS, Brouqui P: Distribution of 'Ehrlichia walkeri' in Ixodes ricinus (Acari: Ixodidae) from the northern part of Italy. $J$ Med Entomol 2005, 42(1):82-5.

28. Piccolin G, Benedetti G, Doglioni C, Lorenzato C, Mancuso S, Papa N, Pitton L, Ramon MC, Zasio C, Bertiato G: A study of the presence of $B$. burgdorferi, Anaplasma (previously Ehrlichia) phagocytophilum, Rickettsia, and Babesia in Ixodes ricinus collected within the territory of Belluno, Italy. Vector Borne Zoonotic Dis 2006, 6(1):24-31.

29. Floris R, Yurtman AN, Margoni EF, Mignozzi K, Boemo B, Altobelli A, Cinco M: Detection and identification of Rickettsia species in the northeast of Italy. Vector Borne Zoonotic Dis 2008, 8(6):777-82.

30. Floris R, Cecco P, Mignozzi K, Boemo B, Cinco M: First detection of Babesia EU1 and Babesia divergens-like in Ixodes ricinus ticks in north-eastern Italy. Parassitologia 2009, 51:23-28.

31. D'Agaro P, Martinelli E, Burgnich P, Nazzi F, Del Fabbro S, lob A, Ruscio M, Pischiutti P, Campello C: Prevalence of tick-borne encephalitis virus in Ixodes ricinus from a novel endemic area of North Eastern Italy. J Med Virol 2009, 81(2):309-16.

32. Cassini R, Bonoli C, Montarsi F, Tessarin C, Marcer F, Galuppi R: Detection of Babesia EU1 in Ixodes ricinus ticks in northern Italy. Vet Parasitol 2010, 171(1-2):151-4.

33. Capelli G, Ravagnan S, Montarsi F, Fusaro A, Ariani P, Cassini R, Martini M, Granato A: Identification and occurrence of Borrelia burgdorferi genospecies in Ixodes ricinus ticks from the main Lyme borreliosis endemic area of Italy. Proceedings of the 3rd Canine Vector-Borne Disease (CVBD) Symposium New York city, USA; 2010, 46-49.

34. Cassini R, Marcer F, di Regalbono AF, Cancrini G, Gabrielli S, Moretti A, Galuppi R, Tampieri MP, Pietrobelli M: New insights into the epidemiology of bovine piroplasmoses in Italy. Vet Parasitol 2012, 184(1):77-82.

35. von Loewenich FD, Geissdörfer W, Disqué C, Matten J, Schett G, Sakka SG, Bogdan C: Detection of "Candidatus Neoehrlichia mikurensis" in two patients with severe febrile illnesses: evidence for a European sequence variant. J Clin Microbiol 2010, 48(7):2630-5.

36. Fehr JS, Bloemberg GV, Ritter C, Hombach M, Lüscher TF, Weber R, Keller PM: Septicaemia caused by tick-borne bacterial pathogen Candidatus Neoehrlichia mikurensis. Emerg Infect Dis 2010, 16(7):1127-9.

37. Welinder-Olsson C, Kjellin $E$, Vaht $K$, Jacobsson $S$, Wennerås C: First case of human "Candidatus Neoehrlichia mikurensis" infection in a febrile patient with chronic lymphocytic leukemia. J Clin Microbiol 2010, 48(5):1956-9.

38. Kawahara M, Rikihisa Y, Isogai E, Takahashi M, Misumi H, Suto C, Shibata S, Zhang C, Tsuji M: Ultrastructure and phylogenetic analysis of 'Candidatus Neoehrlichia mikurensis' in the family Anaplasmataceae, isolated from wild rats and found in Ixodes ovatus ticks. Int I Syst Evol Microbiol 2004, 54(Pt5):1837-43.

39. Andersson $M$, Råberg L: Wild rodents and novel human pathogen candidatus Neoehrlichia mikurensis, Southern Sweden. Emerg Infect Dis 2011, 17(9):1716-8.
40. Süss J: Tick-borne encephalitis 2010: epidemiology, risk areas, and virus strains in Europe and Asia-an overview. Ticks Tick Borne Dis 2011, 2(1):2-15.

41. Schorn S, Pfister K, Reulen H, Mahling M, Manitz J, Thiel C, Silaghi C: Prevalence of Anaplasma phagocytophilum in Ixodes ricinus in Bavarian public parks, Germany. Ticks Tick Borne Dis 2011, 2(4):196-203.

42. Stanek G: Pandora's Box: pathogens in Ixodes ricinus ticks in Central Europe. Wien Klin Wochenschr 2009, 121(21-22):673-83.

43. Reis $C_{1}$ Cote $M$, Paul RE, Bonnet S: Questing ticks in suburban forest are infected by at least six tick-borne pathogens. Vector Borne Zoonotic Dis 2011, 11(7):907-16.

44. Reis C, Cote M, Le Rhun D, Lecuelle B, Levin ML, Vayssier-Taussat M, Bonnet SI: Vector competence of the tick Ixodes ricinus for transmission of Bartonella birtlesii. PLoS Negl Trop Dis 2011, 5(5):e1186.

45. Strube C, Schicht S, Schnieder T: Borrelia burgdorferi sensu lato and Rickettsia spp. infections in hard ticks (Ixodes ricinus) in the region of Hanover (Germany). Berl Munch Tierarztl Wochenschr 2011, 124(1112):512-7.

46. Schicht S, Junge S, Schnieder T, Strube C: Prevalence of Anaplasma phagocytophilum and Coinfection with Borrelia burgdorferi Sensu Lato in the Hard Tick Ixodes ricinus in the City of Hanover (Germany). Vector Borne Zoonotic Dis 2011, 11(12):1595-7.

47. Milhano N, de Carvalho IL, Alves AS, Arroube S, Soares J, Rodriguez P, Carolino M, Núncio MS, Piesman J, de Sousa R: Coinfections of Rickettsia slovaca and Rickettsia helvetica with Borrelia lusitaniae in ticks collected in a Safari Park, Portugal. Ticks Tick Borne Dis 2010, 1(4):172-7.

48. Tomanović S, Radulović Z, Masuzawa T, Milutinović M: Coexistence of emerging bacterial pathogens in Ixodes ricinus ticks in Serbia. Parasite 2010, 17(3):211-7.

49. Mietze A, Strube C, Beyerbach M, Schnieder T, Goethe R: Occurrence of Bartonella henselae and Borrelia burgdorferi sensu lato co-infections in ticks collected from humans in Germany. Clin Microbiol Infect 2011, 17(6):918-20.

50. Rymaszewska A, Adamska M: Molecular evidence of vector-borne pathogens coinfecting dogs from Poland. Acta Vet Hung 2011 59(2):215-23.

51. Nieto NC, Foley JE: Meta-analysis of coinfection and coexposure with Borrelia burgdorferi and Anaplasma phagocytophilum in humans, domestic animals, wildlife, and Ixodes ricinus-complex ticks. Vector Borne Zoonotic Dis 2009, 9(1):93-102.

52. Parola P, Raoult D: Ticks and tickborne bacterial diseases in humans: an emerging infectious threat. Clin Infect Dis 2001, 32:897-928.

53. Braks M, van der Giessen J, Kretzschmar M, van Pelt W, Scholte EJ, Reusken C, Zeller H, van Bortel W, Sprong H: Towards an integrated approach in surveillance of vector-borne diseases in Europe. Parasit Vectors 2011, 4:192.

doi:10.1186/1756-3305-5-61

Cite this article as: Capelli et al:: Occurrence and identification of risk areas of Ixodes ricinus-borne pathogens: a cost-effectiveness analysis in north-eastern Italy. Parasites \& Vectors 2012 5:61.

\section{Submit your next manuscript to BioMed Central and take full advantage of:}

- Convenient online submission

- Thorough peer review

- No space constraints or color figure charges

- Immediate publication on acceptance

- Inclusion in PubMed, CAS, Scopus and Google Scholar

- Research which is freely available for redistribution

Submit your manuscript at www.biomedcentral.com/submit
C Biomed Central 